George Spicer as the College's constitutional law professor.

Bob Harris was one of the University of Virginia's great characters. He combined great charm with wit and wisdom. His kind rarely passes our way. We shall miss him.

Henry J. Abraham

E. Edmond Moomaw

David M. O'Brien

University of Virginia

\section{Richard S. Hartigan}

With Dick Hartigan's death due to cancer on December 26, 1991, Loyola University of Chicago lost one of its most valued faculty members. Prevented by illness from teaching during the spring 1991 term, Dick was able to return to the campus for a day during the fall semester in order to join several other faculty in being recognized for 25 years of service at Loyola. The spontaneous standing ovation that continued for several minutes when the Dean recognized Dick before the faculty of the university was an honest expression of the esteem and respect with which he was held. This outpouring of affection and appreciation was repeated again when both former and current students joined university faculty, staff, and administrators at a memorial service which filled the university's church at its Lake Shore Campus.

Dick was born in the Chicago area but went east to Washington, D.C. to study at Georgetown University. He received his Bachelor's degree in 1958. While an undergraduate studying political science and philosophy, Dick took time to participate in intercollegiate debate. The love of argument and skillful eloquence that one would expect of a successful debater were qualities that Dick brought with him into the classroom to the benefit of his many students.

After a brief flirtation with the possibility of a career in law, Dick entered the Ph.D. program at Georgetown and graduated in 1964 with a dissertation which explored the philosophical origins of noncombatant immunity in international law. This initial interest in the normative control of political action, in general, and of political violence, in particular, is a theme that characterized most of Dick's scholarly work. Each of his three books explored a specific aspect of this general concern. His most recent, The Future Remembered: Biology and Human Values, for which he won the Alpha Sigma Nu Award for the outstanding book in the social sciences published during 1989 , represented the culmination of a theoretical evolution in Dick's own thinking. Earlier, his scholarship focused primarily upon the western natural law tradition in both its rationalist and revelatory forms. Dick studied with great skill the history of western political thought as he explored such topics as the just war tradition and the codes of medieval chivalry in an effort to understand and, when possible, appropriate those normative controls which were most promising. In the mid-1970s Dick's research program underwent a major change, partly in reaction to what he considered to be the naivete of extreme behavioralism and its discounting of human instinct and partly in disappointment with the historical innocence of certain speculative traditions within western metaphysics. Dick turned to the study of biology and ethology in an effort to discover the normative principles which may be operative within the evolution of human nature itself. This development brought Dick into contact with other like-minded scholars and together they founded the Association for Politics and the Life Sciences.

After three years on the faculty of the College of St. Thomas in St. Paul, Dick came to Loyola in the fall of 1966 . He immediately became involved in the life of the university and served on a number of its most important committees. In particular, he was the founder and continuing director of the Frank M. Covey, Jr. Loyola Lecture Series in Political Analysis. Under Dick's direction the lecture series has published eight volumes and is well established as an important program for contemporary political theory.

Dick was a master teacher whose students responded enthusiastically to his enthusiasm, wit, and love of learning. He was particularly proud of having been selected as "Teacher of the Year"' by students in the uni- versity's Honors Program.

Dick is survived by his wife, Nancy, four children, and one grandchild. In his honor Loyola University has established the Richard S. Hartigan Memorial Fund. Contributions may be sent to the Development Office, Loyola University of Chicago, 820 N. Michigan Avenue, Chicago, IL 60611.

James L. Wiser

Loyola University of Chicago

\section{Miriam K. Mills}

Miriam K. Mills, professor of public administration at the New Jersey Institute of Technology, died of colon cancer on March 13, 1992.

Miriam Mills was born May 22, 1938 in Leipzig, Germany. She and her family were on the last train that left Berlin for France on August 31, 1939 before the start of World War II. She spent the war in England as a child, and left to the United States in 1945. She graduated from City College of New York trained as a health-care professional. She then worked as an administrator for hospitals in New Jersey. At age 40, she returned to school and received masters and doctoral degrees in public administration from New York University.

She was a professor at NJIT until her death. On March 12, 1992, the trustees of NJIT promoted her to an endowed professorship in recognition of her teaching, publications, and her service to the university, her profession, and the international community. The professorship was named the Miriam K. Mills Endowed Chair in Public Management.

She was the author and editor of many books in the fields of dispute resolution, health-care policy, decision-aiding software, and developing nations. Her most recent books were Public Policy, Public Administration, and the People's Republic of China (Greenwood Press, 1992), Developing Nations and Super-Optimum Policy Analysis (Nelson Hall Publishers, 1992), Health Insurance and Public Policy (Greenwood Press, 1992), and Systematic Analysis in Dispute Resolution (Quorum Books, 1991). Most of her 17 published books were written 